\title{
Inhibitory effects of tanshinone II-A on invasion and metastasis of human colon carcinoma cells
}

\author{
Yun-feng SHAN, Xian SHEN, Yuan-kang XIE, Ji-cai CHEN, Hong-qi SHI, Zheng-ping YU, Qi-tong SONG, Men-tao ZHOU, Qi-yu \\ ZHANG*
}

Department of General Surgery, the First Affiliated Hospital of Wenzhou Medical College, Wenzhou 325000, China

\begin{abstract}
Aim: To investigate the effects and possible mechanisms of tanshinone II-A, an alcohol extract of the root of Salvia miltiorrhiza Bunge, on tumor invasion and metastasis of human colon carcinoma (CRC) cells.

Methods: The effects of tanshinone II-A on invasion and metastasis of CRC cell lines HT29 and SW480 were evaluated by in vitro and in vivo assays. Western blotting was used to investigate possible molecular mechanisms of tanshinone II-A anti-cancer actions.

Results: Tanshinone II-A inhibited migration and invasion of CRC cells in a dose-dependent manner. The inhibitory effect also depended on time, with the most significant effects observed at $72 \mathrm{~h}$. Tanshinone II-A also significantly inhibited in vivo metastasis of colon carcinoma SW480 cells. It inhibited in vitro and in vivo invasion and metastasis of CRC cells by reducing levels of urokinase plasminogen activator (UPA) and matrix metalloproteinases (MMP)-2 and MMP-9, and by increasing levels of tissue inhibitor of matrix metalloproteinase protein (TIMP)-1 and TIMP-2. Tanshinone II-A was also shown to suppress the nuclear factor-kappaB (NF-kB) signal. Conclusion: Tanshinone II-A inhibited in vitro and in vivo invasion and metastasis of CRC cells. The effect resulted from changes in the levels of UPA, MMP-2, MMP-9, TIMP-1, and TIMP-2, and apparent inhibition of the NF-KB signal transduction pathway.
\end{abstract}

Keywords: metastasis; tanshinone II-A; matrix metalloproteinases; colon cancer; nuclear factor-kappaB; HT29 cells; SW480 cells

Acta Pharmacologica Sinica (2009) 30: 1537-1542; doi: 10.1038/aps.2009.139; published online 12 October 2009

\section{Introduction}

Colorectal cancer (CRC) is the second leading cause of cancerrelated mortality in developed countries ${ }^{[1-3]}$. Over the past several years, therapeutic options for patients with CRC have increased substantially, including earlier diagnosis, improved radical surgery, neoadjuvant chemotherapy, and anti-angiogenesis agents $^{[4]}$. Although mortality can be prevented by surgical resection before tumor cell dissemination ${ }^{[2,3,5]}, 61 \%$ of patients have metastatic disease at presentation and of these, $90 \%$ die within 5 years of diagnosis. Moreover, current adjuvant chemotherapy for metastatic CRC increases median survival by only approximately 14 months ${ }^{[6]}$. These observations highlight the need for rationally designed, targeted therapeutic interventions to manage the metastatic process in CRC patients.

Increasing evidence shows that traditional Chinese medicines can be potential drugs and lead compounds for cancer treatment. Ginsenoside Rg3 inhibits angiogenesis of Lewis

\footnotetext{
* To whom correspondence should be addressed.

E-mail zhangqyqyzhang@yahoo.com.cn

Received 2009-06-01 Accepted 2009-08-12
}

lung carcinoma ${ }^{[7,8]}$, metastasis of intestinal adenocarcinomas and B16 melenoma ${ }^{[9,10]}$, and proliferation of prostate cancer cells $^{[11,12]}$. Recent reports showed that tanshinone II-A, an alcohol extract of the root of Salvia miltiorrhiza Bunge, could reverse malignant phenotypes and inhibit the growth of CRC and hepatocarcinoma cells ${ }^{[13-15]}$. Tanshinone II-A is a traditional Chinese medicine that is known to have anti-inflammatory activity ${ }^{[16,17]}$. It induces differentiation of a human cervical carcinoma cell line (ME180) and leukemia cell lines (NB4, HL-60, and K562) ${ }^{[15,16,18-20]}$. However, no data have been published on whether tanshinone II-A can inhibit invasion and metastasis in colon carcinoma cells. Here, we investigate the effects of tanshinone II-A on the human colon carcinoma cell lines HT29 and SW480 using in vitro and in vivo assays for invasion and metastasis. We investigate possible molecular mechanisms for the effects of tanshinone II-A by examining levels of proteins involved in migration and metastasis, specifically urokinase plasminogen activator (uPA), the matrix metalloproteinase (MMP)-2 and MMP-9 and a tissue inhibitor of matrix metalloproteinase protein (TIMP)-1. To identifiy potential signalling pathways, we also investigate the activation of the nuclear factor-kappaB (NF-kB) pathway after tanshinone II-A treatment. 


\section{Materials and methods}

\section{Cell culture and materials}

The human colon carcinoma cell lines HT29 and SW480 were obtained from the American Type Culture Collection. HT29 cells were cultured in 1640 medium (Sigma-Aldrich), while SW480 cells were cultured in L-15 medium (Sigma-Aldrich). Media were supplemented with $10 \%$ fetal bovine serum (Atlanta Biologicals), and cells were cultured at $37{ }^{\circ} \mathrm{C}$ in $5 \%$ $\mathrm{CO}_{2}$.

\section{Drugs and treatment}

Tanshinone II-A (Pharmasi Chemicals Co, Ltd) was obtained from Institute of Traditional Chinese Medicine, Jiangsu Nanjing Zelang Pharmaceutical Co, China at a purity of $98 \%$. It was dissolved in DMSO to a final concentration of $0.2 \mathrm{mg} / \mathrm{L}$. The solution was filtered through a $0.22 \mu \mathrm{m}$ micropore filter and stored at $4{ }^{\circ} \mathrm{C}$, then diluted further in cell culture medium ${ }^{[19]}$. HT29 and SW480 cells were seeded in flasks or dishes. The tanshinone II-A group was treated with different doses $(0.5,1.0,1.5,2,2.5 \mathrm{mg} / \mathrm{L})$, for $24,48,72$, and $96 \mathrm{~h}$. The negative control group was treated with an equal concentration of DMSO. The cells were measured over $96 \mathrm{~h}$ of treatment.

\section{Wound-healing assay}

For monolayer wound-healing assays, a total of $2 \times 10^{5}$ cells were collected and plated in a 12-well plate. At $100 \%$ confluence, two parallel wounds of $1 \mathrm{~mm}$ were made using a pipette tip. Wound size after $24 \mathrm{~h}$ was measured using Zeiss LSM Image Browser software, version 3.1, in three independent experiments.

\section{In vitro invasion assay}

Cell invasion assays were performed as described previously $^{[21]}$ using Transwells ( $8 \mu \mathrm{m}$ pore size, Corning Costar Corp). A $50 \mu \mathrm{g}$ aliquot of matrigel solution was placed on the lower surface of a polycarbonate filter and incubated at $37^{\circ} \mathrm{C}$ for $2 \mathrm{~h}$ to produce an artificial basement membrane. After rinsing with PBS, the filters were placed into wells, and $600 \mu \mathrm{L}$ of 1640 or L-15 medium containing $10 \%$ bovine serum was added to the lower compartment. HT29 or SW480 cells, either with or without tanshinone II-A at different doses, were added to the upper compartment of the chamber $(100 \mu \mathrm{L}$ serum-free 1640 or L-15 containing $5 \times 10^{4}$ cells), and $600 \mu \mathrm{L}$ of conditioned medium was added to the lower chamber. After 24, 48, 72 and $96 \mathrm{~h}$ incubations, cells were removed from the upper surface of the filter with a cotton swab; the cells that had invaded the bottom surface of the filter were fixed with methanol and stained with hematoxylin. The invasive ability was determined as the number of penetrating cells seen under a microscope at $200 \times$ magnification in 10 random fields per well. Each experiment was performed in triplicate.

\section{In vitro migration assay}

The in vitro migration assay was performed as previously described $^{[21]}$ using Transwells $(8 \mu \mathrm{m}$ pore size, Corning Costar
Corp) without matrigel, and was similar to the invasion assay. HT29 or SW 480 cells were suspended at $2 \times 10^{4} / \mathrm{mL}$. The incubation time was $24 \mathrm{~h}$. Each experiment was performed in triplicate.

\section{Tail vein metastatic assay}

The tail vein metastatic assay was analyzed as previously described ${ }^{[21]}$. Nude mice were handled using best humane practices and were cared for in accordance with NIH Animal Care and Use Committee guidelines. Cells were harvested from tissue culture flasks using trypsin and washed three times with PBS. Mice were injected with $1 \times 10^{6}$ cells in 0.1 $\mathrm{mL}$ PBS through the tail vein. The mice were monitored for overall health and total body weight. Injected mice were randomly assigned into a control group C0 $\left(0 \mathrm{mg} \cdot \mathrm{kg}^{-1} \cdot \mathrm{d}^{-1}\right)$, or intervention groups $\mathrm{C} 1\left(5 \mathrm{mg} \cdot \mathrm{kg}^{-1} \cdot \mathrm{d}^{-1}\right), \mathrm{C} 2\left(20 \mathrm{mg} \cdot \mathrm{kg}^{-1} \cdot \mathrm{d}^{-1}\right)$ or C3 $\left(80 \mathrm{mg} \cdot \mathrm{kg}^{-1} \cdot \mathrm{d}^{-1}\right)$. Each experimental group contained 10 mice. Daily intragastric adminstration of tanshinone II-A was given for five consecutive weeks, beginning $24 \mathrm{~h}$ after tail vein injection. Five weeks later, mice were sacrificed. Liver tissues were observed with visually, and the number of visible tumors on the liver surface was counted. Serial sections were made of the liver tissue before it was hemoxylin and eosin (HE) dyed and observed under a light microscope.

\section{Preparation of nuclear extracts.}

After treatment, cells were harvested and washed twice with ice-cold PBS, and resuspended in $1 \mathrm{~mL}$ of PBS. Nuclear extracts were prepared on ice as previously described ${ }^{[22]}$. After centrifugation at $13000 \mathrm{r} / \mathrm{min}$, the cell pellet was suspended in ice-cold buffer (10 mmol/L HEPES, $1.5 \mathrm{mmol} / \mathrm{L} \mathrm{MgCl}_{2}, 0.2$ $\mathrm{mmol} / \mathrm{L} \mathrm{KCl}, 0.2 \mathrm{mmol} / \mathrm{L}$ phenylmethylsulphonylfluoride, $0.5 \mathrm{mmol} / \mathrm{L}$ dithothreitol), vortexed for $10 \mathrm{~s}$ and centrifuged at $13000 \mathrm{r} / \mathrm{min}$ for $5 \mathrm{~min}$. The nuclear pellet was washed in $1 \mathrm{~mL}$ buffer ( $20 \mathrm{mmol} / \mathrm{L}$ HEPES, $25 \%$ glycerol, $0.42 \mathrm{~mol} / \mathrm{L}$ $\mathrm{NaCl}, 1.5 \mathrm{mmol} / \mathrm{L} \mathrm{MgCl}_{2}, 0.2 \mathrm{mmol} / \mathrm{L}$ EDTA), resuspended in $30 \mathrm{~mL}$ buffer, rotated for $30 \mathrm{~min}$ at $4{ }^{\circ} \mathrm{C}$, and centrifuged for $20 \mathrm{~min}$. The supernatants were used as nuclear extracts and analyzed for protein content by Bradford assay.

\section{Western blot analysis}

Protein extraction and immunoblot analysis was performed as described $^{[23]}$. Cells were washed twice with Hanks' balanced salt solution and lysed directly in RIPA buffer [50 $\mathrm{mmol} / \mathrm{L}$ Tris-HCl pH 7.4, 1\% ( $v / v)$ Triton X-100, 1 mmol/L EDTA, 1 $\mathrm{mmol} / \mathrm{L}$ leupeptin, $1 \mathrm{mmol} / \mathrm{L}$ phenylmethylsulfonyl fluoride, $\left.10 \mathrm{mmol} / \mathrm{L} \mathrm{NaF}, 1 \mathrm{mmol} / \mathrm{L} \mathrm{Na}_{3} \mathrm{VO}_{4}\right]$. Lysates were centrifuged at $14000 \mathrm{r} / \mathrm{min}$ for $30 \mathrm{~min}$ at $4{ }^{\circ} \mathrm{C}$ and supernatants collected. To detect expression of secreted, active MMPs, $10 \mathrm{~mL}$ of conditioned medium was concentrated 100 -fold in $10 \mathrm{kDa}$ microcentrifuge concentrators (Millipore). Cell lysate $(60 \mu \mathrm{g})$ or supernatant proteins $(10 \mu \mathrm{g})$ were separated by SDS-PAGE, blotted onto nitrocellulose membrane, and incubated with mouse monoclonal primary antibody, either anti-uPA (diluted 1:500; Sigma Chemical Co), anti-MMP-2 and anti-MMP-9 (diluted 1:300; Santa Cruz Biotechnology, Santa Cruz, CA), 
anti-TIMP-1 and anti-TIMP-2 (diluted 1: 300; Santa Cruz Biotechnology, Santa Cruz, CA), anti-NF-kB p65 (diluted 1:1000; Santa Cruz Biotechnology, USA), or anti- $\beta$-actin (diluted 1:5000; Sigma Chemical Co) overnight at $4{ }^{\circ} \mathrm{C}$. After repeated washing, membranes were incubated with horseradish-peroxidase-conjugated anti-mouse secondary antibody (Santa Cruz Biotechnology) diluted 1:2000. Bands were visualized using the enhanced chemiluminescence (ECL) system (Amersham Pharmacia Biotech). Each experiment was performed in triplicate.

\section{Statistical analysis}

Stastical analysis was performed with the Kruskal-Wallis rank test, and the Mann-Whitney $U$ test was used to calculate the $P$ value and compare differences in immunohistochemistry data. Assays for characterizing cell phenotypes were analyzed by Student's $t$-test. Statistical SPSS software package (SPSS Inc, Chicago) was used to analyze data. Differences were considered statistically different at $P<0.05$.

\section{Results}

Tanshinone II-A inhibits in vitro invasion and metastasis of CRC cells

We investigated the effects of tanshinone II-A on the invasive and metastatic properties of CRC cells by in vitro invasion and migration assay. Tanshinone II-A inhibited invasion and migration of HT29 and SW480 cells in a dose- and timedependent manner (Tables 1 and 2). At $1 \mathrm{mg} / \mathrm{L}$, an inhibitory effect was noticeable, while at $2 \mathrm{mg} / \mathrm{L}$, the inhibitory rate was $60.25 \%$, with an average inhibition rate of $55.75 \%$ compared to the control group at $48 \mathrm{~h}$. Tanshinone II-A significantly inhibited migration of HT29 and SW480 cells in a Boyden chamber assay without matrigel, with an average inhibition rate of

Table 1A. Number of invasive HT-29 cell after treatment with tanshinone II-A.

\begin{tabular}{lcccccc}
\hline & \multicolumn{5}{c}{ Tanshinone II-A (mg/L) } \\
Time (h) & 0 & 0.5 & 1 & 1.5 & 2 & 2.5 \\
\hline 24 & $31 \pm 8$ & $28 \pm 5$ & $24 \pm 6$ & $18 \pm 5$ & $12 \pm 3$ & $10 \pm 4$ \\
48 & $35 \pm 6$ & $32 \pm 6$ & $28 \pm 5$ & $22 \pm 6$ & $17 \pm 5$ & $13 \pm 3$ \\
72 & $47 \pm 8$ & $44 \pm 7$ & $38 \pm 9$ & $31 \pm 5$ & $26 \pm 5$ & $19 \pm 4$ \\
96 & $53 \pm 5$ & $49 \pm 9$ & $42 \pm 7$ & $36 \pm 6$ & $30 \pm 7$ & $23 \pm 5$ \\
\hline
\end{tabular}

Table 1B. Number of invasive SW480 cell after treatment with tanshinone II-A.

\begin{tabular}{ccccccc}
\hline & \multicolumn{5}{c}{ Tanshinone II-A (mg/L) } \\
Time (h) & 0 & 0.5 & 1 & 1.5 & 2 & 2.5 \\
\hline 24 & $28 \pm 5$ & $27 \pm 5$ & $23 \pm 5$ & $18 \pm 6$ & $14 \pm 7$ & $10 \pm 3$ \\
48 & $39 \pm 8$ & $36 \pm 4$ & $30 \pm 3$ & $25 \pm 7$ & $20 \pm 5$ & $16 \pm 3$ \\
72 & $54 \pm 7$ & $52 \pm 8$ & $45 \pm 6$ & $37 \pm 5$ & $28 \pm 5$ & $22 \pm 7$ \\
96 & $63 \pm 9$ & $60 \pm 11$ & $52 \pm 9$ & $43 \pm 8$ & $32 \pm 6$ & $24 \pm 5$ \\
\hline
\end{tabular}

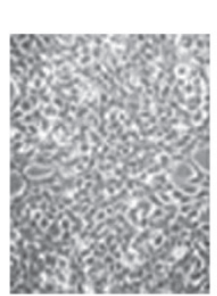

$0 \mathrm{mg} / \mathrm{L}$

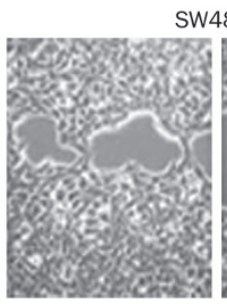

$0.5 \mathrm{mg} / \mathrm{L}$
SW480

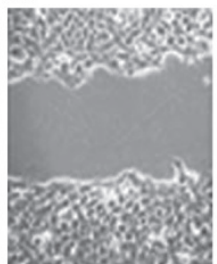

$1 \mathrm{mg} / \mathrm{L}$

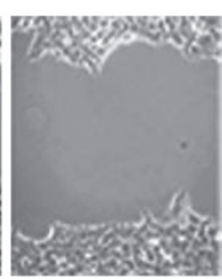

$2 \mathrm{mg} / \mathrm{L}$
Figure 1. Migratory ability of SW480 cells. Cell migration was evaluated by wound healing assay after $24 \mathrm{~h}$ incubation with $0,0.5,1.0$, or $2 \mathrm{mg} / \mathrm{L}$ tanshinone II-A.

$53.15 \%$ compared to the control group at $24 \mathrm{~h}$. As shown in Figure 1 similar results were observed in a wound healing assay. The inhibitory effect increased with time, as seen at the $24,48,72$, and 96 h timepoints. The most significant effect was seen at $48 \mathrm{~h}$ (Table 2). Thus, in vitro invasion and migration assays suggested that tanshinone II-A had the ability to inhibit colon carcinoma metastasis.

\section{Tanshinone II-A inhibits in vivo metastasis of CRC cells}

The CRC cell line SW480 has invasive abilities, including the ability to metastasize to many organs, including liver and lung in nude mice. We examined the effects of tanshinone II-A on in vivo metastasis of SW480 cells using a tail vein assay in nude mice. Tanshinone II-A obvioulsy inhibited metastasis to the liver after tail vein injection of SW480 cells (Table 3). The tumor inhibition rates, measured by the appearance of visible tumors on the liver, in the C2 $\left(20 \mathrm{mg} \cdot \mathrm{kg}^{-1} \cdot \mathrm{d}^{-1}\right)$ and C3 $\left(80 \mathrm{mg} \cdot \mathrm{kg}^{-1} \cdot \mathrm{d}^{-1}\right)$ groups were $40.37 \%$ and $61.15 \%$, respectively (Figure 2, both $P<0.05$ ). It suggested that tanshinone II-A

Table 2A. Number of migratory HT29 cell after treatment with tanshinone II-A.

\begin{tabular}{lllllll}
\hline & \multicolumn{5}{c}{ Tanshinone II-A (mg/L) } \\
Time (h) & 0 & 0.5 & 1 & 1.5 & 2 & 2.5 \\
\hline 24 & $48 \pm 7$ & $43 \pm 8$ & $38 \pm 9$ & $31 \pm 7$ & $23 \pm 6$ & $18 \pm 4$ \\
48 & $66 \pm 5$ & $62 \pm 8$ & $56 \pm 5$ & $45 \pm 10$ & $33 \pm 8$ & $25 \pm 7$ \\
72 & $81 \pm 10$ & $77 \pm 11$ & $70 \pm 8$ & $66 \pm 8$ & $47 \pm 11$ & $31 \pm 5$ \\
96 & $95 \pm 15$ & $90 \pm 16$ & $84 \pm 12$ & $73 \pm 12$ & $55 \pm 8$ & $38 \pm 8$ \\
\hline
\end{tabular}

Table 2B. Number of migratory SW480 cell after treatment with tanshinone II-A.

\begin{tabular}{lcccccc}
\hline & \multicolumn{7}{c}{ Tanshinone II-A (mg/L) } \\
Time (h) & 0 & 0.25 & 0.5 & 1 & 1.5 & 2 \\
\hline 24 & $58 \pm 4$ & $52 \pm 6$ & $43 \pm 6$ & $37 \pm 5$ & $32 \pm 3$ & $25 \pm 7$ \\
48 & $74 \pm 8$ & $68 \pm 10$ & $58 \pm 7$ & $49 \pm 9$ & $41 \pm 8$ & $31 \pm 9$ \\
72 & $89 \pm 10$ & $83 \pm 11$ & $76 \pm 9$ & $65 \pm 8$ & $53 \pm 12$ & $39 \pm 10$ \\
96 & $105 \pm 16$ & $97 \pm 18$ & $88 \pm 12$ & $72 \pm 7$ & $64 \pm 9$ & $55 \pm 8$ \\
\hline
\end{tabular}


Table 3. Number of visible tumors in the liver surface of mice treated with different dosages of tanshinone II-A.

\begin{tabular}{lcccc}
\hline Group & $\begin{array}{c}\text { Dose } \\
\left(\mathrm{mg}^{\mathrm{kg}}{ }^{-1} \cdot \mathrm{d}^{-1}\right)\end{array}$ & $\begin{array}{c}\text { Mice } \\
(\text { before/after })\end{array}$ & $\begin{array}{c}\text { Number of } \\
\text { liver metastases }\end{array}$ & $P$-value \\
\hline C0 & 0 & $10 / 10$ & $18 \pm 5$ & \\
C1 & 5 & $10 / 10$ & $15 \pm 4$ & $P>0.05$ \\
C2 & 20 & $10 / 10$ & $10 \pm 4$ & $P<0.05$ \\
C3 & 80 & $10 / 10$ & $5 \pm 3$ & $P<0.01$ \\
\hline
\end{tabular}

Dose refers to $\mathrm{mg}^{\mathrm{kg}} \mathrm{kg}^{-1} \cdot \mathrm{d}^{-1}$ of tanshinone IIA for five weeks and before/after means no treatment of five weeks after tanshinone II-A treatment at the indicated dose. The liver tissues were observed visually, and the number of visible tumors on the liver surface were counted.
A

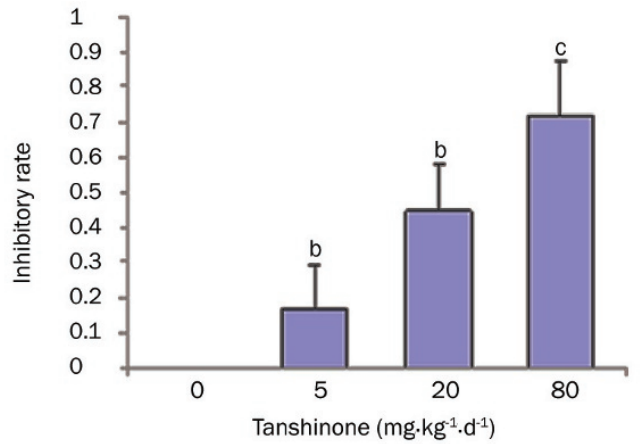

B
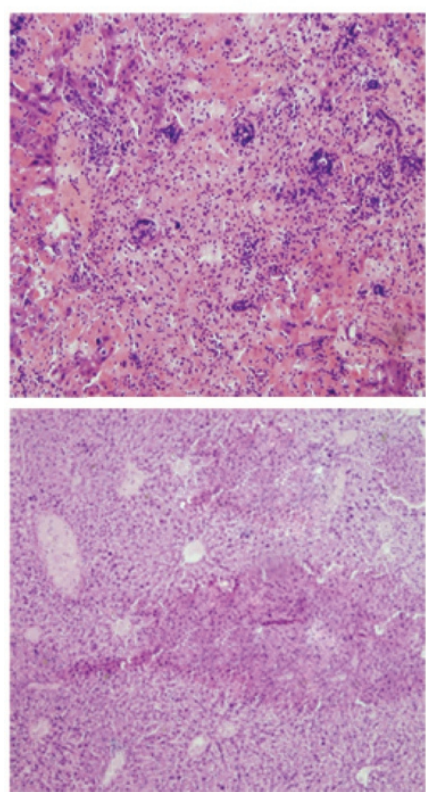

$20 \mathrm{mg} \cdot \mathrm{kg}^{-1} \cdot \mathrm{d}^{-1}$
$5 \mathrm{mg} \cdot \mathrm{kg}^{-1} \cdot \mathrm{d}^{-1}$
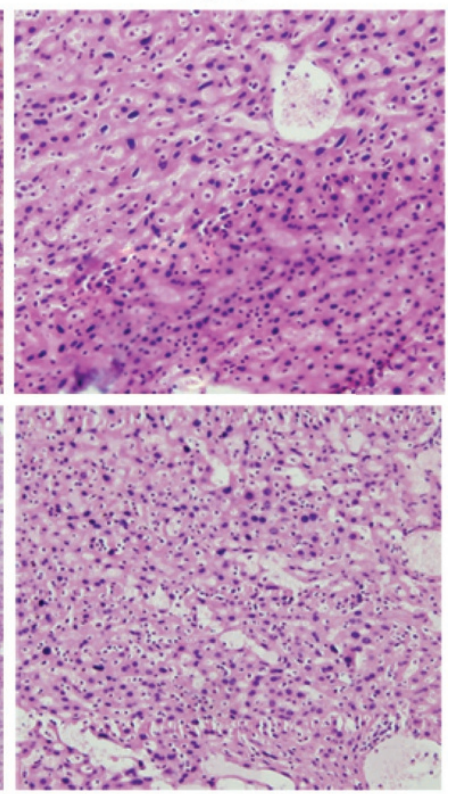

$80 \mathrm{mg} \cdot \mathrm{kg}^{-1} \cdot \mathrm{d}^{-1}$
Figure 2. Effects of tanshinone II-A on metastasis of SW480 cell in nude mice. (A) An in vivo metastasis model was made by injection of SW480 tumor tissue into the livers of nude mice. Experimental and control groups had 10 mice each. Groups were treated with tanshinone II-A at $0,5,20$, or $80 \mathrm{mg} \cdot \mathrm{kg}^{-1} \cdot \mathrm{d}^{-1}$. Four weeks later, the mice were sacrificed and the number of visible tumors on the liver surface was counted. ${ }^{b} P<0.05$, ${ }^{\mathrm{C}} P<0.01$ vs the control group without tanshinone II-A. (B) Serial sections of liver tissues were HE dyed and observed under a light microscope. could inhibit colon carcinoma metastasis.

Tanshinone II-A regulates the expression of UPA, MMP-2, MMP-9, TIMP-1 and TIMP-2 proteins in CRC cells

Extracellular matrix (ECM) degradation is an essential step in tumor invasion and metastasis, and is mainly mediated by a balance between MMPs such as MMP-2 and MMP-9 ${ }^{[24,25]}$, TIMPs, such as TIMP-1 and TIMP-2 ${ }^{[26,27]}$, as well as the serine protease $\mathrm{uPA}^{[28]}$. Therefore, we examined uPA, MMP-2, MMP-9, TIMP-1, and TIMP-2 proteins after tanshinone II-A treatment of CRC cells. Western blotting showed that exposure of SW480 cells to tanshinone II-A resulted in the downregulation of levels of uPA, and the inactive, cytoplasmic proMMP-2 and pro-MMP-9 proteins, as well as their secreted, active forms. TIMP-1 and TIMP-2 levels increased. These effects were time- and dose-dependent (Figure 3). Levels of the $\beta$-actin loading control were similar for all samples.

\section{Involvement of NF-KB in the tanshinone II-A effects on CRC cells}

Previous studies showed that MMPs and TIMPs proteins are regulated via the activation of the NF- $\mathrm{KB}$ transcription factor $^{[29]}$. The p65 protein is a major, phosphorylated subunit of NF-kB, so we investigated levels of phosphorylated p65 in the nucleus of CRC cells after treatment with tanshinone II-A. As shown in Figure 3C, levels of p-p65 in the nuclear fractions of SW480, which we take as a measure of nuclear translocation of NF-kB, was obviously decreased in a dose-dependent manner, by treatment with tanshinone II-A.

\section{Discussion}

For most patients with CRC, liver metastases are the main cause of death ${ }^{[30,31]}$, and the vast majority of patients with distant metastases die within 5 years of diagnosis. Metastasis is mediated by discreet, sequential, rate-limiting steps, including invasion and migration; intravasation and systemic distribution of cancer cells; and seeding, colonization, and proliferation in capillary beds in distant organs ${ }^{[32-34]}$. In this study, we provide evidence that tanshinone II-A can suppress invasion and metastasis of colon carcinoma cells in vitro and in vivo. Invasion and metastasis of solid tumors requires the action of tumor-associated proteases that promote the dissolution of the surrounding tumor matrix and the basement membrane ${ }^{[35]}$. uPA, MMPs and their inhibitors TIMPs, all play an important role in this process in gastric cancer ${ }^{[36-39]}$. In CRC, MMPs mediate fundamental processes underlying the discreet steps in metastasis, including the remodeling of the ECM that is central to invasion and liberation of cancer cells from surrounding tissues $^{[40]}$, and the deployment of locomotory organelles required for matrix adhesion, migration, invasion, and diapedesis ${ }^{[41]}$.

We found that tanshinone II-A was associated with reduced levels of UPA, MMP-2, and MMP-9, and increased levels of TIMP-1 and TIMP-2. In metastasis, uPA and MMP-9 degrade the ECM and basement membrane, mobilizing growth factors that may promote survival, cell migration and invasion. Moreover, uPA directly activates MMP-9 ${ }^{[42]}$, which further contributes to ECM degradation during invasion and tumor 


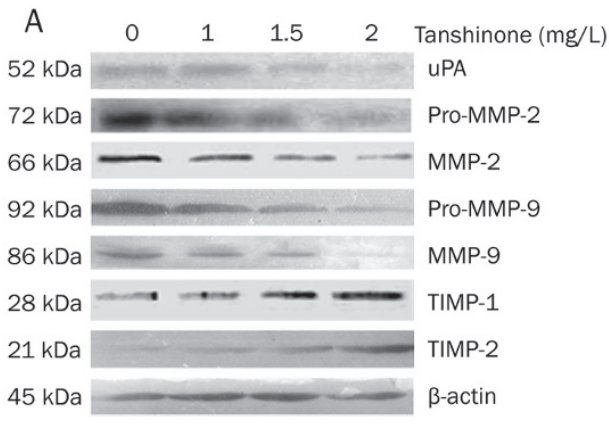

B

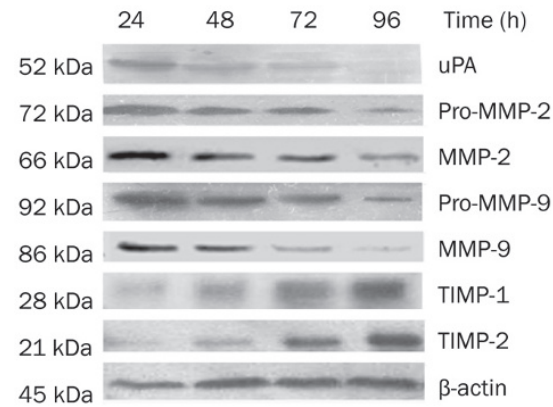

C

\begin{tabular}{|c|c|c|c|c|}
\hline 0 & 1 & 1.5 & 2 & Tanshinone $(\mathrm{mg} / \mathrm{L})$ \\
\hline- & - & - & - & p-p65 \\
\hline & - & 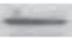 & $\longrightarrow$ & $\beta$-actin \\
\hline
\end{tabular}

Figure 3. The effect of tanshinone II-A on UPA, MMP-2, MMP-9, TIMP-1 and TIMP-2 in colon carcinoma cells. A representative experiment of three with similar results is shown. The expression of UPA, MMP-2, MMP-9, TIMP-1, and TIMP-2 in the cytoplasm, and the active forms of MMP-2 and MMP-9 in the supernatant were evaluated by Western blot. $\beta$-actin was used as an internal control. (A) After $48 \mathrm{~h}$ of incubation with $0,1.0,1.5$, or $2 \mathrm{mg} / \mathrm{L}$ of tanshinone II-A, the levels of UPA, MMP-2, and MMP-9 proteins in colon carcinoma cells decreased, and the levels of TIMP-1 and TIMP-2 proteins in colon carcinoma cells increased dose-dependently, compared to untreated cells $(P<0.05)$. (B) After $24,48,72$, or $96 \mathrm{~h}$ incubation with $2 \mathrm{mg} / \mathrm{L}$ tanshinone II-A, the levels of UPA, MMP-2 and MMP-9 proteins in colon carcinoma cells decreased, and the levels of TIMP-1 and TIMP-2 proteins in colon carcinoma cells increased, time-dependently $(P<0.05)$. $\beta$-actin was used as an internal control. (C) The effect of tanshinone II-A on p-p65 in colon carcinoma cells. A representative experiment of three with similar results is shown. The expression of $p$-p65 in the nucleus was evaluated by Western blot. $\beta$-actin was used as an internal control.

progression. On the basis of our in vitro evidence, we hypothesize that tanshinone II-A inhibits invasion of CRC cells, at least in part by downregulating UPA, MMP-2, and MMP-9 proteins, and upregulating TIMP-1 and TIMP-2.

NF- $\mathrm{KB}$ exists in the cytoplasm bound to an inhibitory protein, ІкB. Previous work showed that NF-kB activation is associated with the expression of MMPs and migration of human aortic smooth muscle cells ${ }^{[33]}$. When NF-kB is activated by phosphorylation on the p65 subunit, ІкB is degraded ${ }^{[44]}$. In this study we evaluated the effect of tanshinone II-A on phosphorylation of the p65 subunit during NF-kB activation. We found that levels of phosphorylated $\mathrm{p} 65$ decreased, which might lead to a decrease in translocation of NF-kB. This effect by tanshinone II-A was dose-dependent.

In summary, we found that tanshinone II-A could significantly inhibit in vitro invasion and metastasis of CRC cells. It also appeared to downregulate the protein expression of metalloproteinases MMP-2 and MMP-9. Tanshinone affected these cell components, with the suggestion of possible direct or indirect effects on cell factors and pathways.

\section{Acknowledgments}

We thank Dr Hai-feng JIN (jhf1@yahoo.cn) for correcting the English.

\section{Author contribution}

Yun-feng SHAN and Qi-yu ZHANG designed the research; Yuan-kang XIE, Ji-cai CHEN and Hong-qi SHI performed the research; Zheng-ping YU and Qi-tong SONG contributed new reagents or analytic tools; Men-tao ZHOU analyzed data and Xian SHEN wrote the paper.

\section{References}

1 Jemal A, Tiwari RC, Murray T. Cancer statistics. CA CancerJ Clin 2004; 54: 8-29.

2 Cresanta JL. Epidemiology of can cer in the United States. Prim Care 1992; 19: 419-41.

3 Greenwald P. Colon cancer overview. Cancer 1992; 70: 1206-15.

4 Wolpin BM, Meyerhardt JA, Mamon HJ, Mayer RJ. Adjuvant treatment of colorectal cancer. CA Cancer J Clin 2007; 57: 168-85.

5 Pihl E, Hughes ES, McDermott FT, Milne BJ, Price AB. Disease-free survival and recurrence after resection ofco lorectal carcinoma. J Surg Oncol 1981; 16: 333-41.

6 Meyerhardt JA, Mayer RJ. Systemic therapy for colorectal cancer. N Engl J Med 2005; 352: 476-87.

7 Zhang Q, Kang X, Zhao W. Antiangiogenic effect of low-dose cyclophosphamide combined with ginsenoside Rg3 on Lewis lung carcinoma. Biochem Biophys Res Commun 2006; 342: 824-8.

8 Kang XM, Zhang QY, Tong DD, Zhao W. Experimental study on antiangiogenesis in mice with Lewis lung carcinoma by low-dose of cyclophosphamide combined with ginsenoside Rg3. Zhongguo Zhong Xi Yi Jie He Za Zhi 2005; 25: 730-3.

9 Iishi H, Tatsuta M, Baba M, Uehara H, Nakaizumi A, Shinkai K, et al. Inhibition by ginsenoside Rg3 of bombesin-enhanced peritoneal metastasis of intestinal adenocarcinomas induced by azoxymethane in Wistar rats. Clin Exp Metastasis 1997; 15: 603-11.

10 Chen J, Peng H, Ou-Yang X, He X. Research on the antitumor effect of ginsenoside Rg3 in B16 melanoma cells. Melanoma Res 2008; 18: 322-9.

11 Kim HS, Lee EH, Ko SR, Choi KJ, Park JH, Im DS. Effects of ginsenosides Rg3 and Rh2 on the proliferation of prostate cancer cells. Arch Pharm Res 2004; 27: 429-35.

12 Liu WK, Xu SX, Che CT. Anti-proliferative effect of ginseng saponins on human prostate cancer cell line. Life Sci 2000; 67: 1297-306.

13 Yuan SL, Huang RM, Wang XJ, Song Y, Huang GQ. Reversing effect of tanshinone on malignant phenotypes of human hepatocarcinoma cell line. World J Gastroenterol 1998; 4: 317-9.

14 Yuan SL, Wei YQ, Wang XJ, Xiao F, Li SF, Zhang J. Growth inhibition and apoptosis induction of tanshinone II-A on human hepatocellular 
carcinoma cells. World J Gastroenterol 2004; 10: 2024-8.

15 Su CC, Chen GW, Kang JC, Chan MH. Growth inhibition and apoptosis induction by tanshinone IIA in human colon adenocarcinoma cells. Planta Med 2008; 74: 1357-62.

16 Fan GW, Gao XM, Wang H, Zhu Y, Zhang J, Hu LM, Su YF, Kang LY, Zhang BL. The anti-inflammatory activities of Tanshinone IIA, an active component of TCM, are mediated by estrogen receptor activation and inhibition of iNOS. J Steroid Biochem Mol Biol 2009; 113: $275-80$.

17 Wu WL, Chang WL, Chen CF. Cytotoxic activities of tanshinones against human carcinoma cell lines. Am J Chin Med 1991; 19: $207-$ 16.

18 Yoon Y, Kim YO, Jeon WK, Park HJ, Sung HJ. Tanshinone IIA isolated from Salvia miltiorrhiza BUNGE induced apoptosis in HL60 human premyelocytic leukemia cell line. J Ethnopharmacol 1999; 68: 121-7.

19 Sung HJ, Choi SM, Yoon Y, An KS. TanshinonellA, an ingredient of Salvia miltiorrhiza BUNGE, induces apoptosis in human leukemia cell lines through the activation of caspase-3. Exp Mol Med 1999; 31: $174-8$.

20 Yuan SL, Huang RM, Wang XJ, Song Y, Huang GQ. Reversing effect of tanshinone on malignant phenotypes of human hepatocarcinoma cell line. World J Gastroenterol 1998; 4: 317-9.

21 Jin H, Pan Y, He L, Zhai H, Li X, Zhao L, et al. p75 neurotrophin receptor inhibits invasion and metastasis of gastric cancer. Mol Cancer Res 2007; 5: 423-33.

22 Luo P, Tan Z, Zhang Z, Li H, Mo Z. Inhibitory effects of salvianolic acid $B$ on the high glucose-Induced mesangial proliferation via NF-kappaBdependent pathway. Biol Pharm Bull 2008 ; 31: 1381-6.

23 Jin H, Pan Y, Zhao L, Zhai H, Li X, Sun L, et al. p75 Neurotrophin receptor suppresses the proliferation of human gastric cancer cells. Neoplasia 2007; 9: 471-8.

24 Guilford P, Hopkins J, Harraway J, McLeod M, McLeod N, Harawira $\mathrm{P}$, et al. E-cadherin germline mutations in familial gastric cancer. Nature 1998; 392: 402-4.

25 El-Rifai W, Powell SM. Molecular biology of gastric cancer. Semin Radiat Oncol 2002; 12: 128-40.

26 Brew K, Dinakarpandian D, Nagase H. Tissue inhibitors of metalloproteinases: evolution, structure and function. Biochim Biophys Acta 2000; 1477: 267-83.

27 Murray GI, Duncan ME, Arbuckle E, Melvin WT, Fothergill JE. Matrix metalloproteinases and their inhibitors in gastric cancer. Gut 1998; 43: 791-7.

28 Khwaja F, Djakiew D. Inhibition of cell-cycle effectors of proliferation in bladder tumor epithelial cells by the p75NTR tumor suppressor. Mol Carcinog 2003; 36: 153-60.

29 Auwardt RB, Mudge SJ, Chen C, Power DA. Inhibition with antisense oligonucleotide suggests that IkappaB-alpha does not form a negative autoregulatory loop for NF-kappaB in mesangial cells. Exp Nephrol 2000; 8: 144-51.

30 Jemal A,Tiwari RC, Murray T, Ghafoor A, Samuels A, Wad E, et al.
Cancer statistics. CA Cancer J Clin 2004; 54: 8-29.

31 Hidekazu K, Kazuhiko H, Kazumi US, Daisuke S, Daniel V, Seongjin P, et al. Vascular endothelial growth factor messenger RNA expression level is preserved in liver metastases compared with corresponding primary colorectal cancer. Clin Cancer Res 2006; 12: 29-33.

32 Lubbe W, Zhou Z, Fu WL, Zuzga D, Schulz S, Fridman R, et al. Tumor epithelial cell matrix metalloproteinase 9 is a target for antimetastatic therapy in colorectal cancer. Clin Cancer Res 2006; 12: 1876-82.

33 Wang $\mathrm{H}, \mathrm{Fu} \mathrm{W}$, Im JH. Tumor cell a3h1integrin and vascular laminin- 5 mediate pulmonary arrest and metastasis. J Cell Biol 2004; 164: 935-41.

34 Fidler IJ. The pathogenesis of cancer metastasis: the "seed and soil" hypothesis revisited. Nat Rev Cancer 2003; 3: 453-8.

35 Cho JY, Chung HC, Noh SH, Roh JK, Min JS, Kim BS. High level of urokinase-type plasminogen activator is a new prognostic marker in patients with gastric carcinoma. Cancer 1997; 79: 878-83.

36 Iwamoto J, Mizokami Y, Takahashi K, Nakajima K, Ohtsubo T, Miura $S$, et al. Expressions of urokinase-type plasminogen activator, its receptor and plasminogen activator inhibitor-1 in gastric cancer cells and effects of Helicobacter pylori. Scand J Gastroenterol 2005; 40: 783-93.

37 Farina AR, Coppa A, Tiberio A, Tacconelli A, Turco A, Colletta G, et al. Transforming growth factor-beta1 enhances the invasiveness of human MDA-MB-231 breast cancer cells by up-regulating urokinase activity. Int J Cancer 1998; 75: 721-30.

38 Kaneko T, Konno H, Baba M, Tanaka T, Nakamura S. Urokinase-type plasminogen activator expression correlates with tumor angiogenesis and poor outcome in gastric cancer. Cancer Sci 2003; 94: 43-9.

39 Matsumura S, Oue N, Nakayama H, Kitadai Y, Yoshida K, Yamaguchi $\mathrm{Y}$, et al. A single nucleotide polymorphism in the MMP-9 promoter affects tumor progression and invasive phenotype of gastric cancer. J Cancer Res Clin Oncol 2005; 131: 19-25.

40 Zeng ZS, Cohen AM, Guillem JG. Loss of basement membrane type IV collagen is associated with increased expression of metalloproteinases 2 and 9 (MMP-2 and MMP-9) during human colorectal tumorigenesis. Carcinogenesis 1999; 20: 749-55.

41 Legrand C, Gilles C, Zahm JM. Airway epithelial cell migration dynamics. MMP-9 role in cell-extracellularmatrix remodeling. J Cell Biol 1999; 146: 517-29.

42 Mazzieri R, Masiero L, Mignatti P. Control of type IV collagenase activity by components of the urokinase-plasmin system: a regulatory mechanism with cell-bound reactants. EMBO J 1997; 16: 2319-32.

43 Jin UH, Suh SJ, Chang HW, Son JK, Lee SH, Son KH, et al. Tanshinone IIA from Salvia miltiorrhiza BUNGE inhibits human aortic smooth muscle cell migration and MMP-9 activity through AKT signaling pathway. J Cell Biochem 2008; 104: 15-26.

44 Bours V, Bonizzi G, Bentires-Alj M, Bureau F, Piette J, Lekeux P, et al. NF-kappaB activation in response to toxical and therapeutical agents: role in inflammation and cancer treatment. Toxicology 2000; 153: 27-38. 